\title{
Establishment of Reference Values of Gamma- Glutamyl-Transferase and Plasma Aminotransferases in Young Congolese
}

\author{
Linel Darrel Ngokana', Fylla Onanga Koumou ${ }^{1,2}$, \\ Landry Aymar Loukanou Mbouaka ${ }^{1}$, Childerick Lékana ${ }^{1}$, \\ Reine Freudlendrich Eboka Loumingou Sakou ${ }^{4}$, Edouard Ngou-Milama ${ }^{7}$, \\ Aliocha Nkodila Natuhoyila ${ }^{5,6}$, Benjamin Longo Mbenza ${ }^{5,6}$, Martin Diatewa ${ }^{1,3}$, \\ Etienne Mokondjimobe ${ }^{1,4,6}$
}

\author{
${ }^{1}$ Laboratory of Biochemistry-Pharmacology, Faculty of Health Sciences, Brazzaville, Congo \\ ${ }^{2}$ Biochemistry Laboratory, University Hospital Center, Brazzaville, Congo \\ ${ }^{3}$ Direction of Scientific Research of the Marien NGOUABI University, Brazzaville, Congo \\ ${ }^{4}$ Clinical Biochemistry Laboratory, National Public Health Laboratory, Brazzaville, Congo \\ ${ }^{5}$ Department of Medicine, Faculty of Medicine, UNIKIN, Kinshasa, DRC \\ ${ }^{6}$ Lomo University of Research, Kinshasa, DRC \\ ${ }^{7}$ Faculty of Health Sciences, Omar Bongho Ondimba University, Libreville, Gabon
}

Corresponding Author: Aliocha Natuhoyila Nkodila

\begin{abstract}
Objectives: Our goal was to contribute to the production of reference values of plasma or serum biochemical markers by determining the reference values of gamma-glutamyl transferase (GGT), aspartate aminotransferase (ASAT) and alanine aminotransferase (ALAT) in young Congolese presumed to be healthy.

Methods: 250 young Congolese presumed to be healthy (125 boys and 125 girls) aged 15 to 25 participated in the study. They were selected according to anamnestic and clinico-biological criteria. Samples were taken on a tube containing EDTA and the resulting plasma was stored at $-20^{\circ} \mathrm{C}$. The KENZA MAX spectrophotometer was used to analyze GGT, ASAT and ALAT. The median and the 2.5-97.5 percentiles were used to set the reference limits for each enzyme. The benchmarks determined were compared with those reported by other Africans, Europeans, Indians and Americans. Results: The established reference values were: GGT 12.15-61.85 IU/L for boys and 7-51.95 IU / 1 for girls $(\mathrm{p}<0.0001)$; ASAT 21.60-94.85 IU/L for boys and 17-84.85 IU/L for girls $(\mathrm{p}=0.0003)$; ALAT 8.30-74.40 IU/L for boys and 8-53.85 IU/L for girls $(\mathrm{p}<0.0001)$. In addition, the comparison between our values and those of other populations showed significant differences.

Conclusion: Our results underline the importance of establishing reference values for plasma enzymes specific to the Congolese population. The use of the values established in the 'other populations could induce errors of judgment by excess or by default.
\end{abstract}

Keywords: Gamma-glutamyltransferase, Aspartate aminotransferase, Alanine aminotransferase, Reference values, Congo.

\section{INTRODUCTION}

Reference values (VR) are essential in clinical diagnosis, laboratory monitoring, management of therapy and assessment of drug toxicity [1]. Many African countries, including the Congo, use RVs established from European and American populations $[2,3]$.

Although these values can be used in African hospitals, they remain questionable 
due to the polymorphism of protein synthesis expression and the stratification of populations in tropical environments. If we add to this the notion of intra-individual, inter-individual, intra-racial and inter-racial biological variability, we understand why the use of the reference values of a given population on another group of individuals could induce errors of judgment by excess or by default $[4,5]$.

However, at present, there are no systematic RVs for young Congolese. Gamma-glutamyltransferase

(GGT), aspartate aminotransferase (ASAT) and alanine aminotransferase (ALAT) are important clinical indicators, especially in the assessment of iatrogenic toxicity during treatment of early stage active pulmonary tuberculosis [6]. Hence the interest of this preliminary study, which contributes to the production of reference values for plasma or serum biochemical markers in presumed healthy young Congolese.

\section{MATERIAL AND METHODS Type, scope and period of the study}

This was a cross-sectional and descriptive study, carried out in the biochemistry service of the National Public Health Laboratory (LNSP) of Brazzaville during the period from September to December 2013.

\section{Study population}

The study population consisted of 250 young Congolese presumed healthy, selected in the biochemistry service of the National Public Health Laboratory (LNSP) of Brazzaville. They were selected retrospectively from the following anamnestic and clinico-biological criteria: HIV serology and negative hepatitis B, absence of any disease or metabolic diseases, no medication (anabolic, etc.), alcohol, tobacco, absence of pregnancy or a particular physiological state, absence of risk factors such as obesity, non-practice of intensive exercises.

\section{Collection methods and sampling techniques}

The samples were taken from subjects fasting for about 12 hours, in a seated position. A volume of 3 to $4 \mathrm{ml}$ of blood was collected in a tube containing EDTA and then centrifuged at 3,000 rpm for 5 minutes by the MODEL 90-1 centrifuge. The resulting plasma was aliquoted and stored at $-20^{\circ} \mathrm{C}$ until use. Thawing was only performed during the assay. Enzyme activities were measured by the Kenza Max spectrophotometer, following the protocols of the manufacturers Cypress Diagnostics for GGT and, Biolabo for ASAT and ALAT.

To minimize errors in assays, reliability (accuracy and precision) was reassessed according to specifications and acceptability standards for use in validation of techniques [7] using the manufacturer's normal control serum Human. The reliability of the techniques is reflected by the observed means and the coefficients of variation which have been interpreted in relation to the coefficients of variation reported by Vassault [7].

\section{Statistical analyzes}

Student's $t$ test re-evaluated the accuracy by comparison between the target values and the observed mean values of the control serum, at risk $\alpha=0.05$. The intraserial (repeatability) and inter-serial (reproducibility) coefficients of variation (CV) were calculated for the reassessment of the precision of the methods used. The median and center value of the 95th percentile (2.5 and 97.5 percentiles) were determined to set the reference limits for each enzyme. The 95th percentile values were taken as the reference values. The Mann-Whitney nonparametric test was used to determine gender differences with a significance level $\mathrm{p}<0.05$.

\section{Ethical considerations}

The data were collected anonymously and confidentially. The privacy and confidentiality of the 
respondents were safeguarded. The three fundamental principles of ethics were respected at the time of the study, namely: the principle of respect for the person, that of beneficence, and that of justice. The protocol for this research study was conducted in accordance with the Declaration of Helsinki and approved by the Committee for Ethics and Research in Health Sciences (CERSSA).

\section{RESULTS}

\section{Description of the sample}

There were 125 boys and 125 girls whose mean age was 19.99-1.94 years with the extremes being 15 and 25 years old. The average age of the girls was close to that of the boys, respectively $19.54 \pm 1.83$ years and $20.43 \pm 1.96$ years.

\section{Reliability of methods}

The re-evaluation of the accuracy and precision of the analytical methods used presented in has shown that they are reliable and allow to exclude analytical biases (Table 1) For the accuracy, the comparison between the target value of the control serum and the mean obtained shows that there is no significant difference between these values. The intra-serial (repeatability) and inter-serial (reproducibility) CVs are between 0.08 and 0.34 (Table 1).

Table 1. Assessment of the reliability of the methods used.

\begin{tabular}{|c|c|c|c|c|c|}
\hline \multirow{2}{*}{$\begin{array}{l}\text { Constituents } \\
\text { analyzed Accuracy }\end{array}$} & \multicolumn{3}{|l|}{ Precision $(n=18)$} & \multicolumn{2}{|l|}{ Précision } \\
\hline & $\begin{array}{l}\text { Control serum target value } \\
\text { (UI/l) }\end{array}$ & $\begin{array}{l}\text { Observed mean } \\
\text { value }(\mathrm{UI} / \mathrm{l})\end{array}$ & $\mathbf{t}_{\mathrm{cal}}$ & $\begin{array}{l}\text { Intra-series } \\
(\mathrm{n}=18) \\
\mathrm{CV}\end{array}$ & $\begin{array}{l}\text { Inter-series } \\
(n=18)\end{array}$ \\
\hline GGT & 41.30 & 47.67 & $0.25^{N S}$ & 0.13 & 0.21 \\
\hline ASAT & 25.80 & 23.44 & $0.29^{N S}$ & 0.08 & 0.11 \\
\hline ALAT & 24.20 & 22.50 & $0.18^{N S}$ & 0.10 & 0.34 \\
\hline
\end{tabular}

The baseline plasma gamma-glutamyltransferase (GGT) values determined in boys are significantly higher than those in girls $(\mathrm{p}<0.0001)$ (Table 2).

Table 2. Reference values (IU / I) of the constituents analyzed
\begin{tabular}{|l|l|l|l|l|}
\hline Variable & $\begin{array}{l}\text { Over all } \\
\text { Me(P2.5-97.5) }\end{array}$ & $\begin{array}{l}\text { Male } \\
\text { Me(P2.5-97.5) }\end{array}$ & $\begin{array}{l}\text { Female } \\
\text { Me(P2.5-97.5) }\end{array}$ & p \\
\hline GGT (UI/L) & $22(8.00-53.00)$ & $26(12.15-61.85)$ & $19(7.00-51.95)$ & $<0.001$ \\
\hline ASAT (UI/L) & $59(17.00-94.00)$ & $62(21.60-94.85)$ & $55(17.00-84.85)$ & 0.003 \\
\hline ALAT (UI/L) & $19(8.00-63.00)$ & $25(8.30-74.4)$ & $17(8.00-53.85)$ & $<0.001$ \\
\hline
\end{tabular}

\section{DISCUSSION}

\section{Study sample size}

The size of the study sample $(\mathrm{n}=$ 250) confirms to the IFCC-LM and CLSI guidelines which recommend including at least 120 subjects per class or subclass for establishing values of reference $[8,9]$. Recently, Sujata W. et al. in India [19] conducted a study with a similar size to ours $(\mathrm{n}=250)$.

\section{Reliability of analytical methods}

The re-evaluation of the accuracy and precision of the analytical methods used presented in has shown that they are reliable and allow to exclude analytical biases (Table 1) For the accuracy, the comparison between the target value of the control serum and the mean obtained shows that there is no significant difference between these values. The intra-serial (repeatability) and inter-serial (reproducibility) CVs are between 0.08 and 0.34 , which confirms that these methods have acceptable precision compared to the CVs reported by Vassault et al. are respectively less than 3.8 and 5 [7].

\section{Reference values}

The baseline plasma gammaglutamyltransferase (GGT) values determined in boys are significantly higher than those in girls $(p<0.0001)$ (Table 2). This difference could be due to additional production of the enzyme from the prostate gland, a gland found only in boys [10]. This result is consistent with those reported in East Africa by Saathoff et al. [11] and Eller et al. [12]. The baseline plasma aspartate 
aminotransferase (ASAT) and alanine aminotransferase (ALAT) values determined are also significantly higher in boys than in girls (Table 2): ASAT ( $\mathrm{p}=$ $0.0003)$, ALAT $(\mathrm{p}<0.0001)$. The sex-related variation of these enzymes is known to exist due to genetic factors and muscle mass which is higher in boys than in girls $[5,10]$. Similar results have been reported in black populations from Kampala in Uganda [12], Kericho in Kenya [13] and Mbeya in Tanzania [11]. The comparison between the reference values of the present study and those reported by other African authors (Table III) shows that our reference intervals of GGT approach those determined by Dosso et al. in Ghana [14] and Juma et al. in Kenya [10]. On the other hand, the 97.5 percentile value reported by Saathoff et al. in Tanzania [11] is significantly higher than that of our series. Our baseline values of ASAT and ALAT determined (Table 3) are significantly higher than those determined in Ghana [14], Tanzania [11], Mozambique [15] and Kenya [10].

Table 3. Reference values (IU / L) of the different enzymes in the selected countries.

\begin{tabular}{|c|c|c|c|c|c|}
\hline \multirow[b]{2}{*}{ Constituents analyzed } & \multicolumn{5}{|l|}{ Countries } \\
\hline & Present study & Ghana [14] & Tanzania [11] & Mozambique [15] & Kenya \\
\hline & $15-25$ years & 18-59 years & $19-48$ years & $18-24$ years & $18-50$ years \\
\hline \multicolumn{6}{|l|}{ GGT } \\
\hline Male & $12.15-61.85$ & $9-71$ & $9.3-120.8$ & $U D$ & $6-69$ \\
\hline Female & $7-51.95$ & $6-53$ & $7.3-1.8$ & $U D$ & $7-49$ \\
\hline Male \& female & $8-53$ & $7-61 *$ & $8.1-107.8^{*}$ & $U D$ & $7-66^{*}$ \\
\hline \multicolumn{6}{|l|}{ ASAT } \\
\hline Male & $21.60-94.85$ & $17-60$ & $15.2-53.4$ & $16.80-45.50$ & $16-47$ \\
\hline Female & $17-84.75$ & $13-48$ & $13.5-35.2$ & $13.50-37$ & déc-33 \\
\hline Male \& female & $17-94$ & $14-51 *$ & $14.3-48.1^{*}$ & $13.70-42.80 *$ & $13-44^{*}$ \\
\hline \multicolumn{6}{|l|}{ ALAT } \\
\hline Male & $8.30-74.40$ & $8-54$ & $9.1-55.3$ & $6.50-53.20$ & $9-42$ \\
\hline Female & $8-53.85$ & $6-51$ & $6.7-44.9$ & $4.80-38.50$ & $6-27$ \\
\hline Male \& female & $8-63$ & $7-51 *$ & $7.7-48.3 *$ & $5-48.20^{*}$ & $7-39 *$ \\
\hline
\end{tabular}

The differences observed between these African countries could be explained by the characteristics of the populations studied, such as the size of the sample, which varies widely for the different studies; age groups that are not identical; analytical techniques which do not always have the same resolving powers; eating habits ; eco-climatic conditions; geographic origin and ethnicity [16, 17].

\begin{tabular}{|c|c|c|c|c|}
\hline \multirow[t]{3}{*}{ Constituents analyzed } & \multicolumn{4}{|c|}{ Percentiles 2.5 - 97.5 (UI/I) } \\
\hline & Present study & France [20] & Inde [18] & U.S.A [19] \\
\hline & $15-25$ year & $U D$ & $15-60$ years & $U D$ \\
\hline \multicolumn{5}{|l|}{ GGT } \\
\hline Male & $12.15-61.85$ & $U D$ & $6.76-51.09$ & $U D$ \\
\hline Female & $7-51.95$ & $U D$ & $3.92-48.70$ & $U D$ \\
\hline Male \& female & $8-53$ & $<35$ & $5-50.60 *$ & $1-94$ \\
\hline \multicolumn{5}{|l|}{ ASAT } \\
\hline Male & $21.60-94.85$ & $U D$ & $14-55$ & $U D$ \\
\hline Female & $17-84.75$ & $U D$ & $13-50.43$ & $U D$ \\
\hline Male \& female & $17-94$ & $5-40$ & $13-52.80^{*}$ & $0-35$ \\
\hline \multicolumn{5}{|l|}{ ALAT } \\
\hline Male & $8.30-74.40$ & $U D$ & $16.80-45.50$ & $U D$ \\
\hline Female & $8-53.85$ & $U D$ & $13.50-37$ & $U D$ \\
\hline Male \& female & $8-63$ & $5-35$ & $13.70-42.80 *$ & $0-35$ \\
\hline
\end{tabular}

The comparison between the reference values of our study and those of countries outside Africa (Table 4) shows that our reference intervals of the GGT are significantly high, compared to those of the
Indians reported by Yadav et al. [18]. In contrast, the 97.5 percentile value of GGT reported by Kratz et al. in the USA [19] is significantly higher than ours. In addition, the reference value of the European GGT 
[20] is lower than that of our series. It has been reported that GGT is twice as high in Africans as in Europeans [21]. The ASAT and ALAT reference values of our sample (Table IV) are significantly high, compared to those of Europeans [18], Indians [20] and Americans [19].

Studies show that there are differences between the values of biochemical parameters of African, European, Indian and American [14-17, 19]. These differences are believed to be due, among other things, to nutritional, environmental and genetic variations [5, 22]. Also an elevation of enzymes in black Africans could be the result of the perpetual infectious and parasitic attacks to which they are exposed [5, 23]. These values should be confirmed by further studies.

\section{CONCLUSION}

The differences observed in this study between our reference intervals and those of other studies indicate the interest of establishing reference values of plasma enzymes specific to the Congolese population. Thus, the use of reference values from other populations could induce interpretation bias in bioclinical analyzes because of the divergence of the ecosystem specific to each human group, and genetic polymorphism. The problem that arises is the transferability of the reference values. This study therefore emphasizes the need to produce reference values specific to each African country or region, such as the Congo Basin for better patient management.

\section{Acknowledgments}

We would like to thank all study participants and the staff of the National Public Health Laboratory (LNSP) for their contribution.

\section{Conflict of Interest}

The authors state that there is no conflict of interest.

Source of Funding: None

\section{Ethical Approval: Approved}

\section{REFERENCES}

1. Henny J, Petitclerc C, Fuentes-Arderiu X, Hyltoft Petersen P, Queraltó J M, Schiele F, Siest G. Réviser le concept de valeurs de référence: une nécessité. Ann Biol clin 2001; 59 (4) : 383-92.

2. Acker P, Maydat L, Trapet P. Quelques constantes biochimiques actuelles de l'Africain congolais normal. Bull Soc Path 1987; $1:$ 460-7.

3. Siby S. Etude de la variation des paramètres biochimiques et hématologiques dans le district de Bamako. Thèse de doctorat en Médecine, Bamako, 2008, 114 p.

4. Ngou-Milama E, Djeki J, Akpona S, Dufillot D, Lebreton Devonne T, Mouray H. Critères de sélection pour l'établissement des valeurs de référence en zone tropicale : Application aux protéines spécifiques CRP, HPT, TRF chez l'enfant gabonais. Biol Clin 1996; manuscrit nº 1648

5. Sakande J, Coulibaly J L, Njikeutchi F N, Bouabre A, Boukary A, Guissou I P Établissement des valeurs de référence de 15 constituants biochimiques sanguins chez l'adulte burkinabé à Ouagadougou (Burkina Faso). Ann Biol Clin 2004; 62 (2) : 229-34.

6. Mokondjimobe E, Dossou-Yovo R, LongoMbenza B, Akiana J, Ndalla U O, Mboussa J, Parra H J. Biomarkers of oxidative and personalized treatment of pulmonary tuberculosis: Emerging role of gammaglutamyl transferase. Advances in Pharmacological Sciences 2012; 2012 (465634) : 1-7.

7. Vassault A, Grafmeyer D, De Graeve J, Cohen R, Beaudonnet, Bienvenu J. Analyses de biologie médicale : spécifications et normes d'acceptabilité à l'usage de la validation de techniques. Ann Biol Clin 1999; 57 (6) : 685-95.

8. Henny J. Etablissement et validation des intervalles de référence au laboratoire de biologie médicale. Ann Biol Clin 2011; 69 (2) : 229-37.

9. Clinical and laboratory standards institute (CLSI). Defining, establishing and verifying reference intervals in the clinical laboratory; approved guideline, 3 rd ed. CLSI document C28-A3. Wayne, PA: Clinical and Laboratory Standards Institute 2008; 28 (30) : 61 . 
10. Juma A, Njagi E N M, Ngeranwa J J N. Estimation of reference values for liver function tests for adult population in northrift valley, Kenya. Asian Journal of Medical Sciences 2011; 3 (6): 243-49.

11. Saathoff E, Schneider P, Kleinfeldt V, Geis S, Haule D, Maboko L, Samky E, De Souza M, Robb M, Hoelscher M. Laboratory reference values for healthy adults from southern Tanzania. Trop Med Int Health 2008; 13 (5) : 612-25.

12. Eller L A, Eller M A, Ouma B, Kataaha P, Kyabaggu D, Tumusiime R. Reference intervals in healthy adult Ugandan blood donors and their impact on conducting international vaccine trials. PLoS ONE 2008; 3 (12) : 1-6.

13. Kibaya R S, Bautista C T, Sawe F K, Shaffer D N, Sateren W B, Scott P T, Michael N L, Robb M L, Birx D L, De Souza M S. Reference ranges for the clinical laboratory derived from a rural population in Kericho, Kenya. PLoS ONE 2008; 3 (10) $: 1-7$.

14. Dosoo D K, Kayan K, Adu-Gyasi D, Kwara E, Ocran J, Osei Kwakye K, Mahama E, Amenga-Etego S, Bilson P, Asante K P, Koram K A, Owusu-Agyei S. Haematological and biochemical reference values for healthy adults in the middle belt of Ghana. PLoS ONE 2012; 7 (4) : e36308.

15. Tembe N, Joaquim O, Alfai E, Sitoe N, Viegas E, Macovela E, Gonçalves E, Osman $\mathrm{N}$, Andersson S, Jani I, Nilsson C. Reference values for clinical laboratory parameters in young adults in Maputo, Mozambique. PLoS ONE 2014; 9 (5): e97391.

16. Diallo D A, Tall T, Guindo A, Dembélé B K, Algiman E, Diakité A A, Diallo O, Bady $M$. Valeurs de référence de l'hémoglobine $\mathrm{A}_{2}$ dans le district de Bamako au Mali. Technique et Biologie. Elsevier-Masson 2013; 43 : 449-52.
17. Vincent-Viry M, Henny J, Clerc M, Siest G. Discussion sur les limites de référence de populations européennes et africaines. Conclusions pratiques d'étude coopérative internationale. Méd Afr Noire 1987; 34 (5) : 459-65.

18. Yadav D, Gupta M, Mishra S, John P J, Sharma P. Establishment of reference interval for liver specific biochemical parameters in apparently healthy north Indian population. Ind $\mathrm{J}$ Clin Biochem 2013; 28 (1) : 30-37.

19. Kratz A, Ferraro M, Sluss P M, Lewandrowski K B. Case records of the Massachusetts General Hospital. Weekly clinicopathological exercises. Laboratory reference values. N Engl J Med 2004; 351 : 1548-63

20. Bakhoum S. Guide médical de poche: Examens biologiques, Edition. Paris: Vernazobres-Grego, 2006, pp. 151-53.

21. Arock M, Bali J P, Ducros V. Gammaglutamyltransferase GGT. American Association for Clinical Chemistry 2009; 18 : 4-6.

22. Yapo A E, Bonetto R, Nebavi-N'guessan G F, Konan Waidhet D, Diafouka F, Monnet D. Profil biochimique de référence normal de l'enfant ivoirien de 0 à 15 ans. Med Afr Noire 1999; 46 (1) : 4-9.

23. Yapo A E, Assayi M J, Aka B, Bonetto R, Lonsdorfer A, Comoe L, Monnet D, Diaine C. Les valeurs de référence de 21 constituants biochimiques sanguins de l'Ivoirien adulte présumé sain. Pharm Afr 1989; 44 : 13-24.

How to cite this article: Linel Darrel Ngokana, Koumou FO, Mbouaka LAL et.al. Establishment of reference values of gammaglutamyl-transferase and plasma aminotransferases in young congolese. Int J Health Sci Res. 2021; 11(9): 259-264. DOI: https:// doi.org/10.52403/ijhsr.20210939 